\title{
Geographical distribution of COPD prevalence in Europe, estimated by an inverse distance weighting interpolation technique
}

This article was published in the following Dove Press journal: International Journal of COPD

\author{
Ignacio Blanco' \\ Isidro Diego ${ }^{2}$ \\ Patricia Bueno ${ }^{3}$ \\ Eloy Fernández ${ }^{4}$ \\ Francisco Casas- \\ Maldonado ${ }^{5}$ \\ Cristina Esquinas ${ }^{6}$ \\ Joan B Soriano ${ }^{7}$ \\ Marc Miravitlles ${ }^{6}$ \\ 'Alphal-Antitrypsin Deficiency \\ Spanish Registry, Lung Foundation \\ Breathe, Spanish Society of \\ Pneumology, Barcelona, ${ }^{2}$ Materials \\ and Energy Department, School of \\ Mining Engineering, Oviedo University, \\ ${ }^{3}$ Internal Medicine Department, \\ County Hospital of Jarrio, ${ }^{4}$ Clinical \\ Analysis Laboratory, University \\ Hospital of Cabueñes, Principality of \\ Asturias, ${ }^{5}$ Pneumology Department, \\ University Hospital San Cecilio, \\ Granada, ${ }^{6}$ Pneumology Department, \\ Hospital Universitari Vall d'Hebron, \\ CIBER de Enfermedades Respiratorias \\ (CIBERES), Barcelona, ${ }^{7}$ Instituto de \\ Investigación Hospital Universitario \\ de la Princesa, Universidad Autónoma \\ de Madrid, Madrid, Spain
}

Correspondence: Marc Miravitlles Pneumology Department, Hospital Universitari Vall d'Hebron, Pg. Vall d'Hebron II9-129, 08035, Barcelona, Spain

Tel +34932746107

Email mmiravitlles@vhebron.net

\begin{abstract}
Existing data on COPD prevalence are limited or totally lacking in many regions of Europe. The geographic information system inverse distance weighted (IDW) interpolation technique has proved to be an effective tool in spatial distribution estimation of epidemiological variables, when real data are few and widely separated. Therefore, in order to represent cartographically the prevalence of COPD in Europe, an IDW interpolation mapping was performed. The point prevalence data provided by 62 studies from 19 countries ( 21 from 5 Northern European countries, 11 from 3 Western European countries, 14 from 5 Central European countries, and 16 from 6 Southern European countries) were identified using validated spirometric criteria. Despite the lack of data in many areas (including all regions of the eastern part of the continent), the IDW mapping predicted the COPD prevalence in the whole territory, even in extensive areas lacking real data. Although the quality of the data obtained from some studies may have some limitations related to different confounding factors, this methodology may be a suitable tool for obtaining epidemiological estimates that can enable us to better address this major public health problem.
\end{abstract}

Keywords: epidemiology, geographic information system, GIS, Geographic Resources Analysis Support System

\section{Introduction}

COPD is a large, growing public health problem. According to the World Health Organization, its expected burden will increase in the coming decades, mostly due to continued exposure to risk factors, population growth and aging, to become the third leading cause of death by $2030{ }^{1}$

Despite being a major health problem, existing data on COPD prevalence are limited in many countries, and universally high COPD underdiagnosis ${ }^{2}$ or misdiagnosis ${ }^{3}$ deprives patients and health authorities of the implementation of adequate preventive and therapeutic measures, in order to avoid its potential serious effects and high costs. ${ }^{4}$ In fact, of the 50 sovereign European countries, only 19 (38\%) of them have available reliable data on COPD prevalence. ${ }^{5}$

The geographic information system (GIS) is considered a useful tool for reporting the distribution of health-related states, in particular diseases. ${ }^{6,7}$ Specifically, the GIS inverse distance weighting (IDW) interpolation (or spatial analysis) technique (an informatics mathematical approach of manipulating spatial information to extract new information and meaning from the original data, using points with known values to estimate values at other unknown points) has proved to be an effective tool in spatial 
distribution estimation of epidemiological variables, when real data are few and widely separated, as might be the case with the COPD prevalence in Europe..$^{8-10}$

The objective of the present study was to apply the IDW mapping to integrate the existing data from different European areas, in order to represent cartographically the mean percentage of the population affected by COPD in each geographical region of the entire continent, both in studied areas with known data and in many other areas in which no studies have been conducted and consequently with blank data.

\section{Methods}

\section{Source of epidemiological studies for COPD prevalence}

The vast majority of the data entered in the database used in the IDW interpolation software were taken from the systematic review and meta-analysis recently published by Adeloye et al on the prevalence of COPD across the world from January 1990 to December 2014, based on a confirmed diagnosis of COPD with different formally acknowledged spirometric criteria. ${ }^{5}$ For the current study, only the variables referring to the place of origin of the samples and the mean COPD prevalence (in percent) of the samples composed of subjects aged $\geq 40$ years were used. ${ }^{11-63}$ To the initially selected 61 studies, a later one on the prevalence of COPD, as defined by the Global Initiative for Obstructive Lung Disease (GOLD), in a representative sample of northeastern Italy general population was added. ${ }^{64}$

The application of an age selection criterion of $\geq 40$ years excluded, from the present study, an international study that included young subjects from several cities in Europe aged between 20 and 44 years, ${ }^{65} 2$ studies performed in 12 Russian regions, ${ }^{66,67}$ and another study of the Turkish region of Elazig all of them carried out in subjects from the age of $18 .^{68}$

In addition, to facilitate visual comparisons between Europe and the neighboring regions of Asia and Africa, the available COPD prevalence data from several Middle East and North Africa regions were also included. ${ }^{69-77}$

\section{IDW multivariate interpolation method}

To elaborate colored geographical maps of COPD prevalence, an IDW interpolation process was started through the freely available software QGIS 18.9 in order to link it with the 7.3 64-bit wxPython 3 Geographic Resources Analysis Support System (GRASS).

Then, the geographical longitude and latitude coordinates of the different places were automatically obtained for each point by translating the location of the place of origin of the samples included. The translation was made through the Google Maps application programming interface using the web page of GPS Visualizer (Carleton University Library, Ottawa, ON, Canada).

Then, these geographical coordinates were imported into the database and then exported to a "csv" (comma separated value) text file, which was opened and visualized in QGIS. A shape file containing the contours of all world countries was also loaded.

Finally, the interpolation process was carried out by applying the "v.surf.idw" library included in the GRASS GIS version 7, another free and open source GIS software suite used for geospatial data management and analysis, spatial modeling, image processing, graphics and maps production, and visualization.

The v.surf.idw library provided surface interpolation from vector point data by filling out a raster matrix with interpolated values generated from a set of irregularly spaced data points, using numerical approximation (weighted averaging) techniques. The interpolated value of a cell was determined by the values of the nearby data points and the distance of the cell from those input points.

An implementation of an IDW technique, as defined by Shepard, ${ }^{7}$ is as follows: the way to find an interpolated value $u$ at a given (arbitrary) point $\mathrm{x}$ based on $\mathrm{N}$ known samples $\mathrm{u}_{\mathrm{i}}=\mathrm{u}\left(\mathrm{x}_{\mathrm{i}}\right)$ for $\mathrm{i}=1,2, \ldots, \mathrm{N}$ is:

$$
\begin{gathered}
u(x)= \begin{cases}\frac{\sum_{\mathrm{i}=1}^{\mathrm{N}} \mathrm{w}_{\mathrm{i}}(\mathrm{x}) \mathrm{u}_{\mathrm{i}}}{\sum_{\mathrm{i}=1}^{\mathrm{N}} \mathrm{w}_{\mathrm{i}}(\mathrm{x})} & \text { if } \mathrm{d}\left(\mathrm{x}, \mathrm{x}_{\mathrm{i}}\right) \neq 0 \text { for all } \mathrm{i} \\
\mathrm{u}_{\mathrm{i}} & \text { if } \mathrm{d}\left(\mathrm{x}, \mathrm{x}_{\mathrm{i}}\right)=0 \text { for some } \mathrm{i}\end{cases} \\
\text { where } \mathrm{w}_{\mathrm{i}}(\mathrm{x})=\frac{1}{\mathrm{~d}\left(\mathrm{x}, \mathrm{x}_{\mathrm{i}}\right)^{\mathrm{p}}}
\end{gathered}
$$

The "N known samples" is the $\mathrm{N}$ closest ones to the interpolation point. In our study, the usual $\mathrm{N}$ value of 4 $(\mathrm{N}=4)$ was chosen. This means that a sample point takes the 4 closest pixel centers and linearly interpolates their color values according to their distance from the sample point; $\mathrm{p}$ is called the power parameter, which has a default value of 2 , which was the value used in this study.

To express the range of values in the maps, a progressive gradient (low-high) range scale of 10 colors, creating a diverging low-mid-high color gradient, with dark blue tones representing the lowest values, yellow and green representing the intermediate ones, and brown and dark red representing the highest ones, was used. 


\section{Geographical regions of Europe}

Although there is not a universally accepted definition of the boundaries and countries of the European regions, to facilitate the description of findings, we used a simple and conventional classification of the regions of Europe into 5 major subregions, namely Northern Europe, Western Europe, Central Europe, Southern Europe, and Eastern Europe. ${ }^{79}$

Northern Europe consists approximately of the Europe regions above the 52nd parallel north, and in this geographical area, the following countries have been included for this study: Iceland, Denmark, Norway, Sweden, Finland, Estonia, Latvia, and Lithuania.

In Western Europe, the following countries have been included: the Netherlands, Belgium, Luxembourg, France, Ireland, and UK.

In Central Europe, the following countries have been included: Germany, Austria, Poland, Slovakia, Czech Republic, Hungary, Slovenia, and Switzerland.

In Southern Europe, the following countries have been included: Spain, Portugal, Italy, Greece, Malta, Cyprus, and Turkey.

Although there is no consensus on the precise area covered by Eastern Europe, because the term has a wide range of geopolitical, geographical, cultural, and socioeconomic connotations, the following countries have been included in this region: the Balkan Peninsula countries (Albania,
Croatia, Bosnia and Herzegovina, Montenegro, Serbia, and Macedonia), Romania, Moldova, Bulgaria, Ukraine, Belarus, and European Russia.

\section{Statistical analysis}

Descriptive statistics were used to summarize study sites. Quantitative variables were expressed as mean and $\mathrm{SD}, 95 \% \mathrm{CI}$ for the mean, and range, and they were analyzed using the analysis of variance. A $p<0.05$ was considered statistically significant. Statistical calculations were performed using the analytical software SPSS 19 (IBM Corp., Armonk, NY, USA).

\section{Results \\ The cohorts}

A total of 62 studies from 19 countries ( 21 from 5 Northern European countries, 11 from 3 Western European countries, 14 from 5 Central European countries, and 16 from 6 Southern European countries) were selected (Tables 1-4). As mentioned previously, no prevalence data were available for any of the 12 countries from Eastern Europe.

Numbers of point estimates by individual countries (from high to less) were as follows: Sweden, 8; United Kingdom, 7; Norway, 5; Finland, Germany, and Turkey, 4 each; the Netherlands, Austria, Poland, Portugal, and Spain, 3 each; Italy and Greece, 2; and other remaining countries, 1 .

Table I Mean prevalence of COPD in 21 studies from 5 Northern Europe countries

\begin{tabular}{|c|c|c|c|c|c|c|}
\hline Country & $\begin{array}{l}\text { Source of } \\
\text { samples }\end{array}$ & Setting & $\begin{array}{l}\text { Age } \\
\text { (years) }\end{array}$ & $\begin{array}{l}\text { Diagnosis } \\
\text { criteria }\end{array}$ & $\begin{array}{l}\text { COPD } \\
\text { prevalence (\%) }\end{array}$ & Study \\
\hline Denmark & Copenhagen & Urban & 63 & GOLD & 17 & Fabricius et al'" \\
\hline Denmark & Copenhagen & Urban & 50 & GOLD & 25 & Maio et $\mathrm{al}^{12}$ \\
\hline Denmark & Aarhus and Aalborg & Mixed & 65 & GOLD & 12 & Hansen et $\mathrm{al}^{13}$ \\
\hline Finland & Helsinki & Urban & 49 & GOLD/LLN & 6 & Kainu et $\mathrm{al}^{14}$ \\
\hline Finland & Lahti & Rural & 48 & GOLD & 9 & Jyrki-Tapani et al ${ }^{15}$ \\
\hline Finland & Lieto & Rural & 73 & $\mathrm{FEV}_{\mathrm{I}} / \mathrm{FVC} \leq 65 \%$ & 8 & Isoaho et $\mathrm{al}^{16}$ \\
\hline Finland & Ylöjärvi & Mixed & 55 & GOLD & 5 & Kanervisto et al $^{17}$ \\
\hline Iceland & Reykjavik & Urban & 57 & GOLD & 18 & Benediktsdóttir et al ${ }^{18}$ \\
\hline Norway & Hordaland county & Mixed & 55 & GOLD & 9 & Waatevik et al ${ }^{19}$ \\
\hline Norway & Bergen municipality & Mixed & 61 & GOLD & 9 & Hvidsten et $\mathrm{al}^{20}$ \\
\hline Norway & Bergen & Urban & 58 & GOLD & 19 & Buist et $\mathrm{al}^{21}$ \\
\hline Norway & Hordaland county & Mixed & 42 & GOLD & 5 & Bakke et $\mathrm{al}^{22}$ \\
\hline Norway & Bergen municipality & Mixed & 46 & GOLD & 5 & Johannessen et $\mathrm{al}^{23}$ \\
\hline Sweden & Uppsala & Urban & 59 & LLN & 10 & Danielsson et $\mathrm{al}^{24}$ \\
\hline Sweden & Lulea & Rural & 61 & GOLD & 14 & Lindberg et $\mathrm{al}^{25}$ \\
\hline Sweden & Lulea & Rural & 49 & GOLD & 14 & Lindberg et $\mathrm{al}^{26}$ \\
\hline Sweden & Norrbotten county & Rural & 61 & GOLD & II & Lindberg et $\mathrm{al}^{26}$ \\
\hline Sweden & Northern Sweden & Rural & 50 & BTS & 10 & Lindström et $\mathrm{al}^{27}$ \\
\hline Sweden & Stockholm & Urban & 53 & GOLD & 20 & Maio et $\mathrm{al}^{12}$ \\
\hline Sweden & Värmland county & Rural & 45 & BTS & 2 & Hasselgren et $\mathrm{al}^{28}$ \\
\hline Sweden & Örebro & Mixed & 49 & ATS & II & Larsson ${ }^{29}$ \\
\hline
\end{tabular}

Note: The numerical values of age and prevalence have been rounded.

Abbreviations: ATS, American Thoracic Society; BTS, British Thoracic Society; GOLD, Global Initiative for Chronic Obstructive Lung Disease; LLN, lower limit of normal. 
Table 2 Mean prevalence of COPD in II studies from 3 Western Europe countries

\begin{tabular}{|c|c|c|c|c|c|c|}
\hline Country & Source of samples & Setting & $\begin{array}{l}\text { Age } \\
\text { (years) }\end{array}$ & $\begin{array}{l}\text { Diagnosis } \\
\text { criteria }\end{array}$ & $\begin{array}{l}\text { COPD } \\
\text { prevalence (\%) }\end{array}$ & Study \\
\hline France & Paris & Urban & 63 & GOLD & 7 & Roche et $\mathrm{al}^{30}$ \\
\hline the Netherlands & Maastricht & Urban & 59 & GOLD/LLN & 19 & Vanfleteren et $\mathrm{al}^{3 \mid}$ \\
\hline the Netherlands & Rotterdam & Urban & 69 & GOLD & 12 & van Durme et $\mathrm{al}^{32}$ \\
\hline the Netherlands & $\begin{array}{l}\text { General population } \\
\text { of the whole country }\end{array}$ & Mixed & 58 & GOLD & 4 & Afonso et $\mathrm{al}^{33}$ \\
\hline UK & Birmingham & Mixed & 58 & GOLD & 9 & Jordan et $\mathrm{al}^{34}$ \\
\hline UK & Ashington & Urban & 59 & GOLD & 25 & Melville et $\mathrm{al}^{35}$ \\
\hline UK & Greater Belfast area & Mixed & 55 & ATS & 7 & Murtagh et $\mathrm{al}^{36}$ \\
\hline UK & Glasgow & Urban & 51 & GOLD & 24 & Maio et $a^{12}$ \\
\hline UK & Barton-upon-Humber & Mixed & 68 & GOLD & 10 & Dickinson et $\mathrm{al}^{37}$ \\
\hline UK & Manchester & Mixed & 64 & GOLD & 26 & Renwick and Connolly ${ }^{38}$ \\
\hline UK & $\begin{array}{l}\text { General population } \\
\text { of the whole country }\end{array}$ & Mixed & 56 & GOLD & 13 & Shahab et $\mathrm{al}^{39}$ \\
\hline
\end{tabular}

Note: The numerical values of age and prevalence have been rounded.

Abbreviations: ATS, American Thoracic Society; GOLD, Global Initiative for Chronic Obstructive Lung Disease; LLN, lower limit of normal.

Accordingly, a total of 329,413 subjects from the 4 regions of Europe with published data were studied; they were distributed as follows: 39,836 in Northern Europe; 229,083 in Western Europe; 25,553 in Central Europe; and 34,941 in Southern Europe.

The size of the selected samples was significantly different in the 4 European regions, with a mean (minimum and maximal values in parentheses) of 1,897 (548-6,525) subjects in Northern Europe; $20,751(246-185,325)$ in Western Europe; 1,825 (432-6,126) in Central Europe; and 2,329 (500-9,061) in Southern Europe.

Most of the studies were conducted in isolated cities or localized regions of a particular country, while only a few were carried out on samples representative of the adult general population of an entire country, such as those performed in the Netherlands, ${ }^{33} \mathrm{UK},{ }^{39}$ Switzerland, ${ }^{50}$ Portugal,,${ }^{52}$ Spain, ${ }^{54,55}$ and Cyprus. ${ }^{60}$

According to the study base of the samples, 23 of them were classified as urban ( 7 from Northern Europe, 4 from Western Europe, 7 from Central Europe, and 5 from Southern Europe), 9 (6 from Northern Europe, 1 from Central Europe, and 2 from Southern Europe) were classified as rural, and the remaining 30 were catalogued as mixed.

The mean age of the subjects from the 62 selected samples was 55.9 years $(\mathrm{SD}=6.1$ ), without significant differences between regions (Table 5).

In $80 \%$ of the studies, the diagnosis of COPD was made by using the GOLD spirometric criteria of the

Table 3 Mean prevalence of COPD in 14 studies from 5 Central Europe countries

\begin{tabular}{|c|c|c|c|c|c|c|}
\hline Country & Source of samples & Setting & $\begin{array}{l}\text { Age } \\
\text { (years) }\end{array}$ & $\begin{array}{l}\text { Diagnosis } \\
\text { criteria }\end{array}$ & $\begin{array}{l}\text { COPD } \\
\text { prevalence (\%) }\end{array}$ & Study \\
\hline Austria & Salzburg & Mixed & 58 & GOLD & 17 & Weiss et $\mathrm{al}^{40}$ \\
\hline Austria & Salzburg & Urban & 59 & GOLD & 26 & Schirnhofer et $\mathrm{al}^{41}$ \\
\hline Austria & Vienna & Urban & 56 & GOLD & 20 & Maio et $\mathrm{al}^{12}$ \\
\hline Germany & Hannover & Mixed & 58 & GOLD & 13 & Geldmacher et $\mathrm{al}^{42}$ \\
\hline Germany & Dusseldorf & Urban & 59 & GOLD & 9 & Gingter et $\mathrm{a}^{43}$ \\
\hline Germany & Munich & Urban & 59 & GOLD & 21 & Maio et $\mathrm{al}^{12}$ \\
\hline Germany & Berlin & Urban & 41 & GOLD & 16 & Maio et $\mathrm{al}^{12}$ \\
\hline Poland & Warsaw & Mixed & 57 & LLN & 9 & Bednarek et al ${ }^{44}$ \\
\hline Poland & Malopolska province & Mixed & 56 & GOLD & 22 & Nizankowska-Mogilnicka et $\mathrm{al}^{45}$ \\
\hline Poland & Warsaw & Urban & 49 & GOLD & II & Plywaczewski et $\mathrm{al}^{46}$ \\
\hline Poland & Lublin region & Rural & 50 & GOLD & II & Paprzycki et al ${ }^{47}$ \\
\hline Poland & Bytom & Mixed & 59 & GOLD & 6 & Siatkowska et al ${ }^{48}$ \\
\hline Slovenia & Sezana (Carso) & Urban & 56 & GOLD & 10 & Grzetic-Romcevic et al ${ }^{49}$ \\
\hline Switzerland & $\begin{array}{l}\text { General population } \\
\text { of the whole country }\end{array}$ & Mixed & 54 & GOLD & 5 & Bridevaux et $\mathrm{al}^{50}$ \\
\hline
\end{tabular}

Note: The numerical values of age and prevalence have been rounded.

Abbreviations: GOLD, Global Initiative for Chronic Obstructive Lung Disease; LLN, lower limit of normal. 
Table 4 Mean prevalence of COPD in 15 studies from 6 Southern Europe countries

\begin{tabular}{|c|c|c|c|c|c|c|}
\hline Country & Source of samples & Setting & $\begin{array}{l}\text { Age } \\
\text { (years) }\end{array}$ & $\begin{array}{l}\text { Diagnosis } \\
\text { criteria }\end{array}$ & $\begin{array}{l}\text { COPD } \\
\text { prevalence (\%) }\end{array}$ & Study \\
\hline Portugal & Lisbon & Urban & 63 & GOLD & 14 & Bárbara et $\mathrm{al}^{51}$ \\
\hline Portugal & General population of the whole country & Mixed & 56 & GOLD & 9 & Cardoso et $\mathrm{al}^{52}$ \\
\hline Portugal & Porto & Urban & 58 & GOLD & 11 & Mascarenhas et $\mathrm{a}^{53}$ \\
\hline Spain & Multicenter study on II cities & Mixed & 57 & GOLD & 10 & Miravitlles et $\mathrm{al}^{54}$ \\
\hline Spain & Multicenter study on 7 geographical areas & Mixed & 54 & ERS & 9 & Peña et $a^{55}$ \\
\hline Spain & Canary Islands & Urban & 55 & GOLD & 7 & Cabrera López et a $\left.\right|^{56}$ \\
\hline Italy & Po Delta area & Rural & 57 & GOLD & 23 & Viegi et $\mathrm{al}^{57}$ \\
\hline Italy & Verona & Mixed & 56 & GOLD/LLN & 12 & Guerriero et $\mathrm{a}^{64}$ \\
\hline Greece & Exochi, Thessaloniki & Mixed & 52 & GOLD & 6 & Sichletidis et $\mathrm{al}^{58}$ \\
\hline Greece & Thessaly region & Rural & 54 & GOLD & 18 & Minas et $\mathrm{a}^{59}$ \\
\hline Cyprus & General population of the whole island & Mixed & 54 & GOLD & 5 & Zachariades et $\mathrm{al}^{60}$ \\
\hline Turkey & Kocaeli city & Urban & 56 & GOLD & 13 & Arslan et $\mathrm{a}^{61}$ \\
\hline Turkey & Erzurum & Rural & 55 & GOLD & 5 & Erdogan et $a^{62}$ \\
\hline Turkey & Malatya region & Mixed & 47 & ATS/ERS & 7 & Gunen et $\mathrm{a}^{63}$ \\
\hline Turkey & Adana & Mixed & 54 & GOLD & 19 & Buist et $\mathrm{a}^{21}$ \\
\hline
\end{tabular}

Note: The numerical values of age and prevalence have been rounded.

Abbreviations: ATS, American Thoracic Society; ERS, European Respiratory Society; GOLD, Global Initiative for Chronic Obstructive Lung Disease; LLN, lower limit of normal.

postbronchodilator (post-BD) fixed ratio $\mathrm{FEV}_{1} / \mathrm{FVC}<0.70$; in the remaining 12 studies, other spirometric criteria (not post-BD) endorsed by different scientific societies were used, such as the lower limit of normal, the British Thoracic Society, the American Thoracic Society, and European Respiratory Society criteria.

\section{COPD prevalence}

The global mean prevalence of COPD (expressed in percent) was 12.38 ( $\mathrm{SD}=6.2$ ) without significant differences among the 4 European regions with available data (Table 6).

The highest values of prevalence were found in 2 samples from the cities of Manchester and Salzburg (26\% each), followed by those of Ashington and Copenhagen (with 25\% each); the COPD subjects from Glasgow, the Po Delta area of Italy, and the southern Poland region of Malopolska (with $24 \%, 23 \%$, and $22 \%$, respectively); and the COPD subjects from the metropolitan areas of Stockholm and Vienna (with $20 \%$ each).
Prevalence rates between $\geq 15 \%$ and $\leq 20 \%$ were found in the cities of Bergen and Maastricht and in the Turkish province of Adana (all with 19\%), in the metropolitan areas of Reykjavik and Thessaly (both 18\%), and in Berlin (with 16\%).

Prevalence ranges between $\geq 10 \%$ and $\leq 15 \%$ were found in a sample from Luleå (in the northernmost county of Sweden) with 14\%, followed by 2 samples from Bartonupon-Humber (England) and Hannover (Germany) both with $13 \%$ and the patients' samples from the Danish cities of Aarhus and Aalborg and the Dutch city of Rotterdam (with 12\%). Prevalence value of $11 \%$ was found in Warsaw, in the Polish region of Lublin, and in the Swedish counties of Norrbotten and Örebro. Prevalence values slightly $>10 \%$ were found in Slovenia, Spain, and Portugal and in the general population of the UK.

In practically all of the remaining places with available data, prevalence ranged from 5 to $<10 \%$. Anecdotally, a young rural cohort, with a mean age of 45 years, from the

Table 5 Ages of selected samples, descriptive statistics

\begin{tabular}{|c|c|c|c|c|c|c|c|}
\hline Region & $\begin{array}{l}\text { Number of } \\
\text { studies }\end{array}$ & $\begin{array}{l}\text { Mean } \\
\text { (years) }\end{array}$ & SD & $\begin{array}{l}95 \% \mathrm{Cl} \\
\text { (lower limit) }\end{array}$ & $\begin{array}{l}95 \% \mathrm{Cl} \\
\text { (upper limit) }\end{array}$ & Minimum & Maximum \\
\hline Northern Europe & 21 & 54.8 & 7.7 & 51.3 & 58.3 & 42.0 & 73.0 \\
\hline Western Europe & II & 60.3 & 5.6 & 56.5 & 64.0 & 50.9 & 69.5 \\
\hline Central Europe & 14 & 55.0 & 5.2 & 52.0 & 58.1 & 40.1 & 59.5 \\
\hline Southern Europe & 16 & 55.2 & 3.2 & 53.5 & 56.9 & 47.5 & 62.8 \\
\hline Global & 62 & 55.9 & 6.1 & 54.4 & 57.5 & 40.8 & 73.0 \\
\hline
\end{tabular}

Note: Interregions: $p=0.07$ I, no significant differences (ANOVA).

Abbreviation: ANOVA, analysis of variance. 
Table 6 COPD prevalence in Europe, descriptive statistics

\begin{tabular}{|c|c|c|c|c|c|c|c|}
\hline Region & $\begin{array}{l}\text { Number of } \\
\text { studies }\end{array}$ & $\begin{array}{l}\text { Mean } \\
\text { prevalence (\%) }\end{array}$ & SD & $\begin{array}{l}95 \% \mathrm{Cl} \\
\text { (lower limit) }\end{array}$ & $\begin{array}{l}95 \% \mathrm{Cl} \\
\text { (upper limit) }\end{array}$ & Minimum & Maximum \\
\hline Northern Europe & 21 & II.5 & 5.9 & 8.8 & 14.1 & 2.1 & 25.4 \\
\hline Western Europe & 11 & 14.2 & 8.0 & 8.8 & 19.6 & 3.9 & 26.4 \\
\hline Central Europe & 14 & 14.1 & 6.5 & 10.4 & 17.9 & 5.0 & 26.1 \\
\hline Southern Europe & 16 & 10.8 & 5.6 & 7.8 & 13.8 & 4.9 & 23.4 \\
\hline Global & 62 & 12.4 & 6.2 & 10.8 & 14.0 & 2.1 & 26.4 \\
\hline
\end{tabular}

Note: Interregions: $p=0.3460$, no significant differences (ANOVA)

Abbreviation: ANOVA, analysis of variance.

Swedish county of Värmland showed the lowest prevalence of COPD in Europe, with a percentage slightly $>2 \%$.

\section{IDW interpolation maps}

In the IDW interpolation map of Figure 1, the prevalence rates of COPD of all European countries are represented by a red-blue scale. Black spots indicate the places of origin of the samples.

In a simplified way, since there is no exact equivalence between the qualitative data provided by the color scale and the quantitative ones provided by the numerical values, it can be interpreted with reasonable certainty that red tones represent the maximum values $>20 \%$; brown and orange colors symbolize high but lower values of $\sim 15 \%-20 \%$; shades of yellow and green tones represent intermediate values of $\sim 10 \%-15 \%$; and blue tones represent minimal values of $0 \%-5 \%$.
The greatest numbers of black spots are located in the Iberian Peninsula, Great Britain, Central Europe, and the coastal regions bordering the North and the Baltic Seas. In contrast, spots are in general scattered and scanty in most of the remaining parts of the continent and absolutely absent in the Mediterranean islands of Corsica, Sardinia, Sicily and Greek islands, southern Italy, Balkan Peninsula, and regions belonging to Eastern Europe.

Some black spots can also be seen in some nearby countries of North Africa and Middle East (for guidance).

In Figure 2, the numerical values of the corresponding prevalence rates have been added. The numerical values appear with a decimal and are the same reproduced (rounded) in Tables 1-4.

In the map of Figure 3, both black spots and numerical figures have been removed to allow a clearer view of the colors with which the different regions were colored.

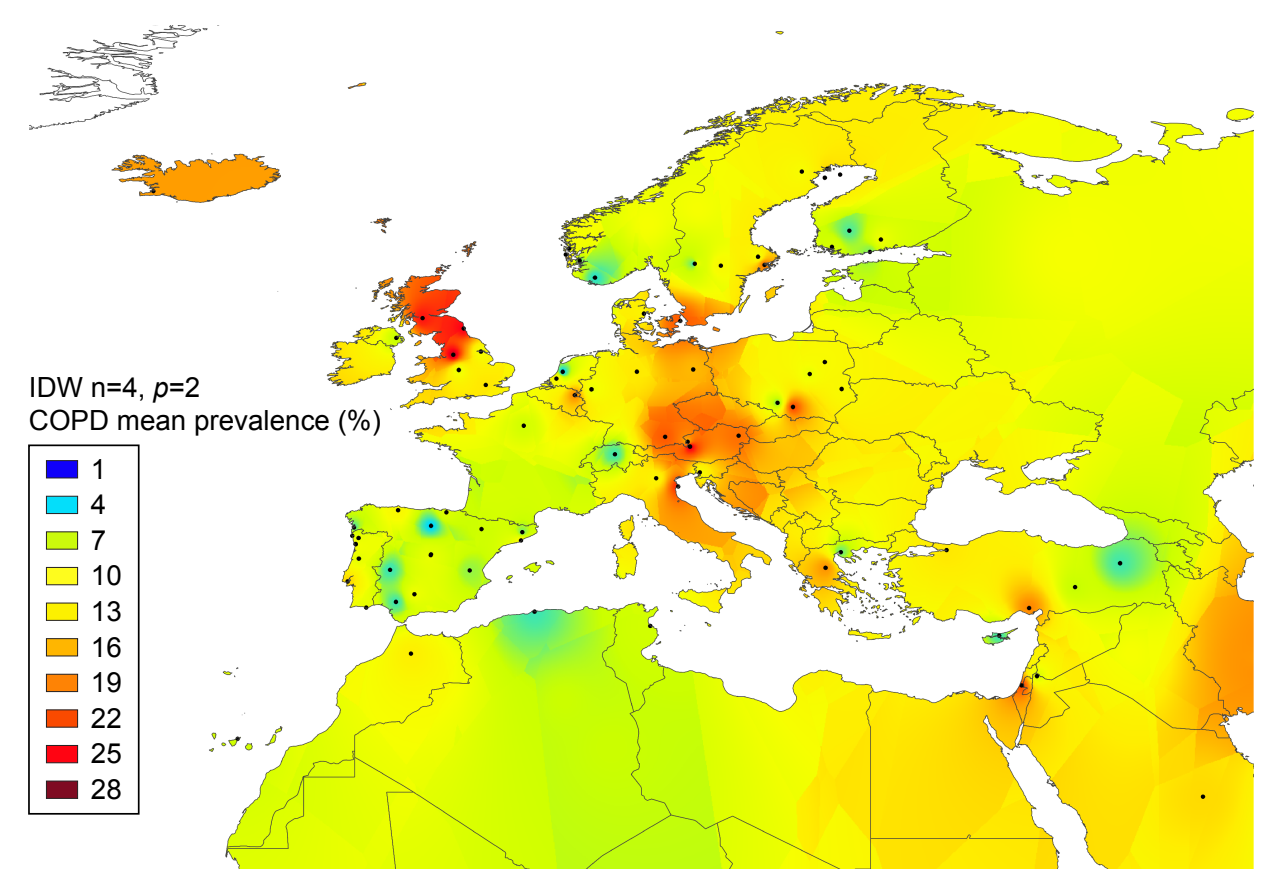

Figure I COPD mean prevalence in Europe.

Notes: In this IDW interpolation map, the COPD prevalence is represented by a red-blue scale. Black spots indicate the places of origin of the data obtained from 62 selected studies. Some black spots are also shown in some nearby countries of North Africa and Middle East for guidance.

Abbreviation: IDW, inverse distance weighting. 


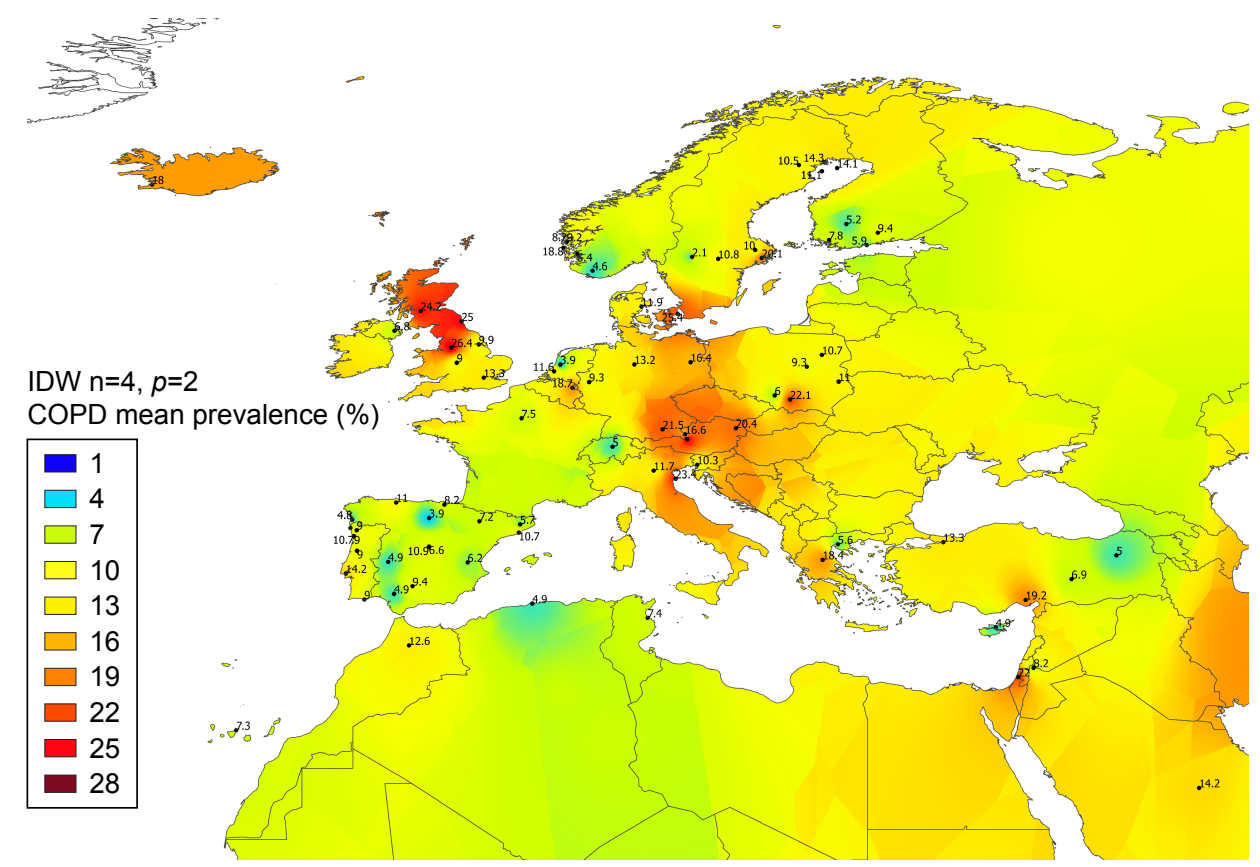

Figure 2 COPD mean prevalence in Europe.

Note: The IDW interpolation map shows the prevalence values of COPD at the points of origin of the patients, both in Europe and in some neighboring countries in North Africa and the Middle East.

Abbreviation: IDW, inverse distance weighting.

A very high prevalence represented by red tones $(\approx 20 \%-27 \%)$ appears in practically all Great Britain, except in the south of the island that presents brownish colors in the west and yellow in the center and east consistent with an intermediate prevalence. Reddish colors, indicative of a very high prevalence, are also shown in the southeast of the Scandinavian Peninsula, the Island of Amager (Denmark), southeast of Germany, western and southern Poland, Austria,

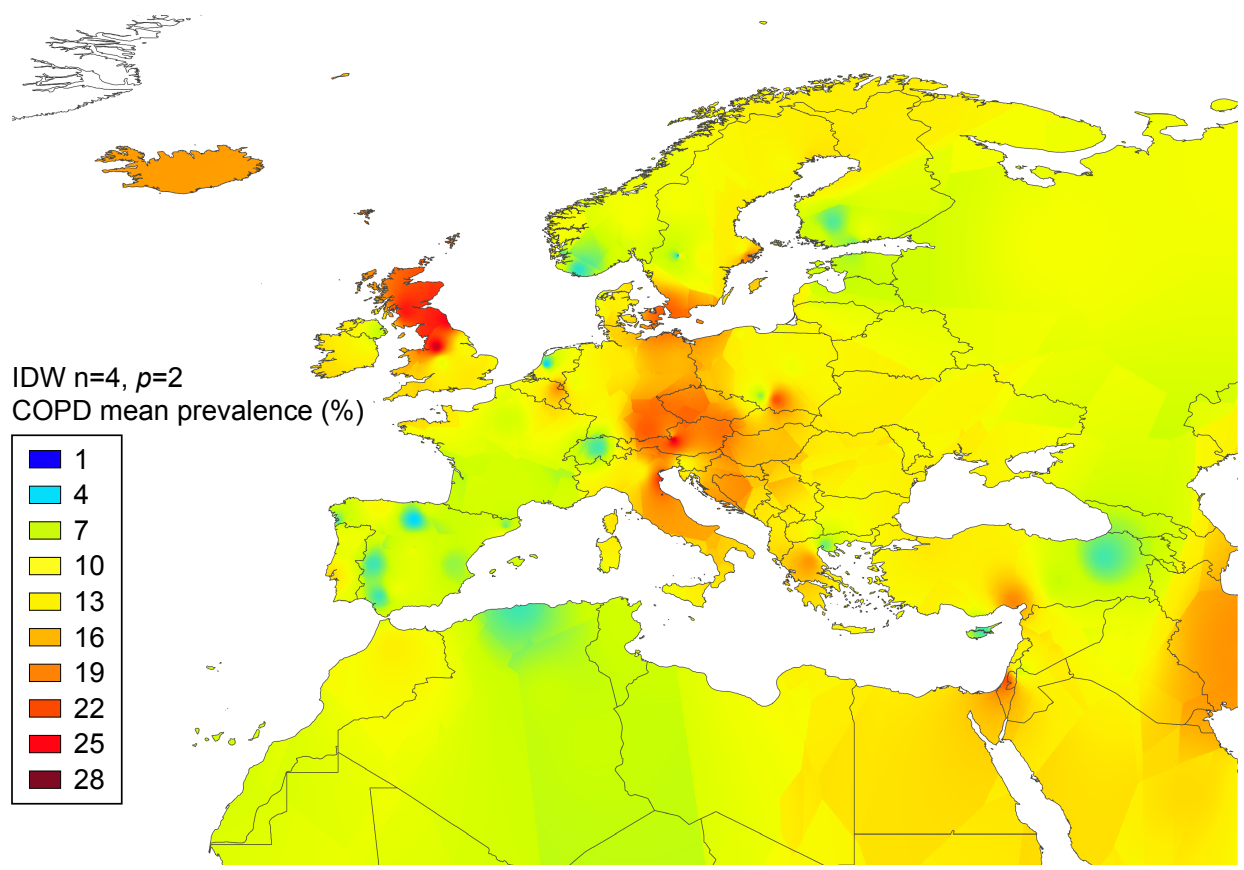

Figure 3 COPD mean prevalence in Europe.

Notes: In this IDW interpolation map, spots and numerical values have been removed to allow a clearer view of the colors with which the different regions appear colored. Although there is not an exact equivalence between the qualitative data provided by the color scale and the numerical values obtained from published studies, there is an approximate correlation between them, which allows interpreting findings of the mapping with reasonable certainty.

Abbreviation: IDW, inverse distance weighting. 
Czech Republic, and Slovakia (these last 2 countries without studies and therefore without real numerical values).

Brown and orange tones (approximately equivalent to a range of numerical values between $15 \%$ and $20 \%$ ) appear in Iceland, Hungary, large areas of Italy (except the regions of Lombardy, Piedmont, Liguria, and Calabria, which appear in yellow color), Croatia, Bosnia and Herzegovina, Serbia, and Greece, as well as in the province of Adana (southern Turkey). Of note, there are no real numerical values for the Balkan countries that were colored by means of the IDW mapping.

Most of the remaining regions of Europe are stained in yellow and green colors, indicative of an intermediate prevalence of $\sim 10 \%-15 \%$; the Danish peninsula of Jutland, most of Sweden, Norway, and northern Finland, the Baltic seacoast countries and the Baltic islands of Gotland and Aland, Belorussia, most of the lands of Poland, the western half of Germany, the coastal regions of Western Europe and Great Britain bordering the North Sea and the English Channel, Ireland, Portugal, Spain, the Mediterranean major islands, Slovenia, Ukraine, Romania, Bulgaria, European Russia, Montenegro, Albania, Macedonia, and the Anatolian Peninsula are included in this group. Remarkably, many of these regions were stained by IDW interpolation in the absence of real numerical data.

Blue areas (indicative of the prevalence of around or $<5 \%$ ) are scarce and isolated; Switzerland, the island of Cyprus, some cities of Spain, such as Vigo, Burgos, Cáceres, and Seville, scattered areas of the Scandinavian peninsula and Finland, and the Erzurum Province of eastern Turkey are among them.

\section{Discussion}

Existing data on COPD prevalence are in general insufficient and irregularly distributed in many regions of Europe, in some of which there is a striking scarcity or even an absolute lack of epidemiological information about this important health issue.

To assess the COPD prevalence throughout the European continent and its surrounding islands, an efficient method of proven utility, known as IDW multivariate interpolation (or spatial analysis), which is usually applied to various disciplines concerned with the earth's surface, such as cartography, geography, hydrology, climatology, and agriculture, was used in the present study in order to generate a continuous map of COPD prevalence.

Basically, IDW interpolation uses data points with known values to estimate other values at unknown locations, in order to create a raster surface consisting of an array of cells (pixels) arranged in rows and columns (or a grid) in which each cell contains a value representing some prevalence information, finally covering a whole area. The IDW method is based on the assumption that the attribute value of an unsampled point is the weighted average of known values within the 4 nearest data points. IDW assumes that each measured point has a local influence that diminishes with distance, weighting the points closer to the prediction location greater than those located farther away, which means that weights are inversely related to the distances between the sampled locations and the predicted ones. ${ }^{7}$

The IDW interpolation is a simple and intuitive method, easy to handle and interpret, relatively fast for calculations, and easy to compute, which also has the advantage of allowing to easily renewing the database, with a flexibility of the inclusion of studies newly identified, that are more recent, or with a better study design. Similar flexibility applies to the exclusion of others of less scientific quality to automatically reconstructing new, updated maps. In addition, IDW has a mathematical precision that makes it always exact, but this advantage can be a disadvantage if the actual data were erroneous or inaccurate. Since it works automatically creating new points from others supposedly accurate, it is crucial to introduce reliable data; otherwise the final results will also be inaccurate or erroneous.

For the present study, the numerical data of prevalence rates were obtained with the best available evidence in publicly accessible scientific databases, and only surveys constituted by patients of at least $\geq 40$ years of age and a confirmed diagnosis of COPD with spirometry were selected for the analysis.

\section{Limitations}

However, the authors of the present study are aware that the analysis may have some limitations due to a number of confounding factors frequently associated with cross-sectional studies, and sometimes these confounding variables could have led to spurious associations. For example, the sampling approach varied from study to study or even among sites in the same study. In addition, the size of the samples was highly variable, with significant differences between regions, and some of them were not proportional to the general population of the studied region. Remarkably, the lack or scarcity of data in extensive regions of Europe makes the scientific hypotheses from which some conclusions were drawn less reliable.

There are also some (though not statistically significant) differences in the age distribution between regions of 
Europe and even within the same region of the same country, and since in spirometry-based studies the prevalence of COPD increases with age, the lack of homogeneity in this variable may be the reason for some of the erratic values.

On the other hand, when modeling relative risks or ORs from data obtained from a given population, results may not be applicable to populations with different levels of exposure, as the relations may not be linear across all exposure levels. Regrettably, in our study, there was no proportionality between the number of urban and rural cohorts, and thus, studies performed in populations with high levels of smoking or occupational air pollutants exposure may not be generalizable to those of populations with lower levels of exposure.

Another limitation may be related to the differences in case definitions. The definition based on post-BD $\mathrm{FEV}_{1} /$ FVC $<0.70$ was used in the large majority ( $80 \%$ ) of studies, but this still does not address all possible sources of variation in case definition, since this fixed ratio criterion may potentially overdiagnose COPD in the elderly and it may underdiagnose COPD in younger patients. Besides, a number of technical issues could have affected the estimates, such as the quality of the commercial models of the spirometers used, the level of training of the operators, and the process of collection and storage of spirometry measurements. ${ }^{2-5}$

Finally, an intrinsic limitation of GIS is that geographic proximity does not take into account borders, which often within Europe mirror a different language or dialect. Common language is a well-established factor for unevenly distributing genes, related to or not to health, and many other social determinants. $^{78}$

Nevertheless, in spite of all these criticisms, it should be emphasized that GIS unquestionably offers a useful new tool in epidemiology, which makes it ever easier to connect spatially referenced physical and social phenomena to population patterns of health, disease, and well-being.

Therefore, in our opinion, the easy-to-interpret and eyecatching impacting results of this technique may contribute to enhancing public health surveillance as well as delineating the prevalence of COPD in Europe and in other countries; to increase the number of doctors who treat this type of patients and the health authorities and national governments' interest in strengthening regulations to address occupational and environmental risk factors, regulate tobacco use, and improve public awareness; to all together increase the rate of diagnoses and to implement the application of preventive and therapeutic measures to avoid potential side effects and unnecessary costs; and to reduce the high global COPD burden in coming years.

\section{Disclosure}

The authors report no conflicts of interest in this work.

\section{References}

1. GBD 2015 Chronic Respiratory Disease Collaborators. Global, regional, and national deaths, prevalence, disability-adjusted life years, and years lived with disability for chronic obstructive pulmonary disease and asthma, 1990-2015: a systematic analysis for the Global Burden of Disease Study 2015. Lancet Respir Med. 2017;5:691-706.

2. Bernd L, Joan BS, Michael S, et al. Determinants of underdiagnosis of COPD in national and international surveys. Chest. 2015;148: 971-985.

3. Fernández-Villar A, Soriano JB, López-Campos JL. Overdiagnosis of COPD: precise definitions and proposals for improvement. $\mathrm{Br} J \mathrm{Gen}$ Pract. 2017;67:183-184.

4. Soriano JB, Rodriguez-Roisin R. Chronic obstructive pulmonary disease overview: epidemiology, risk factors and clinical presentation. Proc Am Thorac Soc. 2011;8:363-367.

5. Adeloye D, Chua S, Lee C, et al. Global and regional estimates of COPD prevalence: systematic review and meta-analysis. J Glob Health. 2015;5:020415.

6. Mitas L, Mitasova H. Spatial interpolation. In: Longley PA, Goodchild MF, Maguire DJ, Rhind DW, editors. Geographical Information Systems (GIS): Principles, Techniques, Management and Applications. New York: John Wiley; 1999:481-492.

7. Shepard D. A two-dimensional interpolation function for irregularlyspaced data. In: Proceedings of the 1968 23rd ACM National Conference. ACM'68; 1968; ACM, New York, NY; 517-524.

8. Blanco I, de Serres FJ, Cárcaba V, Lara B, Fernández-Bustillo E. Alpha-1 antitrypsin deficiency $\mathrm{PI} * \mathrm{Z}$ and $\mathrm{PI} * \mathrm{~S}$ gene frequency distribution using on maps of the world by an inverse distance weighting (IDW) multivariate interpolation method. Hepat Mon. 2012;12(10 HCC):e7434.

9. Blanco I, Bueno P, Diego I, et al. Alpha-1 antitrypsin Pi*Z gene frequency and $\mathrm{P} * \mathrm{ZZ}$ genotype numbers worldwide: an update. Int $J$ Chron Obstruct Pulmon Dis. 2017;12:561-569.

10. Blanco I, Bueno P, Diego I, et al. Alpha-1 antitrypsin Pi*SZ genotype: estimated prevalence and number of SZ subjects worldwide. Int J Chron Obstruct Pulmon Dis. 2017;12:1683-1694.

11. Fabricius P, Lokke A, Marott JL, Vestbo J, Lange P. Prevalence of COPD in Copenhagen. Respir Med. 2011;105:410-417.

12. Maio S, Sherrill DL, MacNee W, et al. The European Respiratory Society spirometry tent: a unique form of screening for airway obstruction. Eur Respir J. 2012;39:1458-1467.

13. Hansen JG, Pedersen L, Overvad K, Omland O, Jensen HK, Sorensen HT. The prevalence of chronic obstructive pulmonary disease among Danes aged 45-84 years: population-based study. COPD. 2008;5: 347-352.

14. Kainu A, Rouhos A, Sovijärvi A, Lindqvist A, Sarna S, Lundbäck B. COPD in Helsinki, Finland: socioeconomic status based on occupation has an important impact on prevalence. Scand J Public Health. 2013; 41:570-578

15. Jyrki-Tapani K, Sovijarvi A, Lundback B. Chronic obstructive pulmonary disease in Finland: prevalence and risk factors. COPD. 2005; 2:331-339.

16. Isoaho R, Puolijoki H, Huhti E, Kivelä SL, Laippala P, Tala E. Prevalence of chronic obstructive pulmonary disease in elderly Finns. Respir Med. 1994;88:571-580.

17. Kanervisto M, Vasankari T, Laitinen T, Heliövaara M, Jousilahti P, Saarelainen S. Low socioeconomic status is associated with chronic obstructive airway diseases. Respir Med. 2011;105:1140-1146.

18. Benediktsdóttir B, Gudmundsson G, Jorundsdottir KB, Vollmer W, Gíslason T. [Prevalence of COPD in Iceland - the BOLD study]. Laeknabladid. 2007;93:471-477. Icelandic.

19. Waatevik M, Skorge TD, Omenaas E, Bakke P, Gulsvik A, Johannessen A. Increased prevalence of chronic obstructive pulmonary disease in a general population. Respir Med. 2013;107:1037-1045. 
20. Hvidsten SC, Storesund L, Wentzel-Larsen T, Gulsvik A, Lehmann S. Prevalence and predictors of undiagnosed chronic obstructive pulmonary disease in a Norwegian adult general population. Clin Respir J. 2010;4:13-21.

21. Buist AS, McBurnie MA, Vollmer WM, et al. International variation in the prevalence of COPD (The BOLD Study): a population-based prevalence study. Lancet. 2007;370:741-750.

22. Bakke PS, Baste V, Hanoa R, Gulsvik A. Prevalence of obstructive lung disease in a general population: relation to occupational title and exposure to some airborne agents. Thorax. 1991;46:863-870.

23. Johannessen A, Omenaas E, Bakke P, Gulsvik A. Incidence of GOLD defined chronic obstructive pulmonary disease in a general adult population. Int J Tuberc Lung Dis. 2005;9:926-932.

24. Danielsson P, Olafsdottir IS, Benediktsdottir B, Gislason T, Janson C. The prevalence of chronic obstructive pulmonary disease in Uppsala, Sweden - the Burden of Obstructive Lung Disease (BOLD) study: crosssectional population-based study. Clin Respir J. 2012;6:120-127.

25. Lindberg A, Bjerg A, Ronmark E, Larsson LG, Lundback B. Prevalence and underdiagnosis of COPD by disease severity and the attributable fraction of smoking: report from the Obstructive Lung Disease in Northern Sweden Studies. Respir Med. 2006;100:264-272.

26. Lindberg A, Jonsson AC, Ronmark E, Lundgren R, Larsson LG, Lundback B. Prevalence of chronic obstructive pulmonary disease according to BTS, ERS, GOLD and ATS criteria in relation to doctor's diagnosis, symptoms, age, gender, and smoking habits. Respiration. 2005; 72:471-479

27. Lindström M, Jönsson E, Larsson K, Lundbäck B. Underdiagnosis of chronic obstructive pulmonary disease in Northern Sweden. Int $J$ Tuberc Lung Dis. 2002;6:76-84.

28. Hasselgren M, Arne M, Lindahl A, Janson S, Lundbäck B. Estimated prevalences of respiratory symptoms, asthma and chronic obstructive pulmonary disease related to detection rate in primary health care. Scand J Prim Health Care. 2001;19:54-57.

29. Larsson M. [Where is the borderline between asthma and "COPD"? Reflections on a diagnostic questionnaire]. Lakartidningen. 1995;92: 1089-1092. Swedish.

30. Roche N, Dalmay F, Perez T, et al. Impact of chronic airflow obstruction in a working population. Eur Respir J. 2008;31:1227-1233.

31. Vanfleteren LE, Franssen FM, Wesseling G, Wouters EF. The prevalence of chronic obstructive pulmonary disease in Maastricht, the Netherlands. Respir Med. 2012;106:871-874.

32. van Durme YMTA, Verhamme KMC, Stijnen T, et al. Prevalence, incidence, and lifetime risk for the development of COPD in the elderly: the Rotterdam study. Chest. 2009;135:368-377.

33. Afonso AS, Verhamme KM, Sturkenboom MC, Brusselle GG. COPD in the general population: prevalence, incidence and survival. Respir Med. 2011;105:1872-1884.

34. Jordan RE, Miller MR, Lam KB, Cheng KK, Marsh J, Adab P. Sex, susceptibility to smoking and chronic obstructive pulmonary disease: the effect of different diagnostic criteria. Analysis of the Health Survey for England. Thorax. 2012;67:600-605.

35. Melville AM, Pless-Mulloli T, Afolabi OA, Stenton SC. COPD prevalence and its association with occupational exposures in a general population. Eur Respir J. 2010;36:488-493.

36. Murtagh E, Heaney L, Gingles J, et al. Prevalence of obstructive lung disease in a general population sample: the NICECOPD study. Eur $J$ Epidemiol. 2005;20:443-453.

37. Dickinson JA, Meaker M, Searle M, Ratcliffe G. Screening older patients for obstructive airways disease in a semi-rural practice. Thorax. 1999;54:501-505.

38. Renwick DS, Connolly MJ. Prevalence and treatment of chronic airways obstruction in adults over the age of 45. Thorax. 1996;51:164-168.

39. Shahab L, Jarvis MJ, Britton J, West R. Prevalence, diagnosis and relation to tobacco dependence of chronic obstructive pulmonary disease in a nationally representative population sample. Thorax. 2006;61:1043-1047.

40. Weiss G, Steinacher I, Lamprecht B, et al. Detection of chronic obstructive pulmonary disease in primary care in Salzburg, Austria: findings from the real world. Respiration. 2014;87:136-143.
41. Schirnhofer L, Lamprecht B, Vollmer WM, et al. COPD prevalence in Salzburg, Austria: results from the Burden of Obstructive Lung Disease (BOLD) study. Chest. 2007;131:29-36.

42. Geldmacher H, Biller H, Herbst A, et al. Die Prävalenz der chronisch obstruktiven Lungenerkrankung (COPD) in Deutschland [The prevalence of chronic obstructive pulmonary disease (COPD) in Germany. Results of the BOLD study]. Dtsch Med Wochenschr. 2008;133: 2609-2614. German.

43. Gingter C, Wilm S, Abholz HH. Is COPD a rare disease? Prevalence and identification rates in smokers aged 40 years and over within general practice in Germany. Fam Pract. 2009;26:3-9.

44. Bednarek M, Maciejewski J, Wozniak M, Kuca P, Zielinski J. Prevalence, severity and underdiagnosis of COPD in the primary care setting. Thorax. 2008;63:402-407.

45. Nizankowska-Mogilnicka E, Mejza F, Buist AS, et al. Prevalence of COPD and tobacco smoking in Malopolska region - results from the BOLD study in Poland. Pol Arch Med Wewn. 2007;117:402-410.

46. Plywaczewski R, Bednarek M, Jonczak L, Zielinski J. [Prevalence of COPD in Warsaw population]. Pneumonol Alergol Pol. 2003;71: 329-335. Polish.

47. Paprzycki P, Panasiuk L, Sodolski W. Prevalence of obstructive respiratory disorders in the rural population of the Lublin region. Ann Univ Mariae Curie Sklodowska Med. 2003;58:72-78.

48. Siatkowska H, Kozielski J, Ziora D. Chronic obstructive pulmonary disease patients in the general practice. Pneumonol Alergol Pol. 2010;78:112-120.

49. Grzetic-Romcevic T, Devcic B, Sonc S. Spirometric testing on World COPD Day. Int J Chron Obstruct Pulmon Dis. 2011;6:141-146.

50. Bridevaux PO, Probst-Hensch NM, Schindler C, et al. Prevalence of airflow obstruction in smokers and never-smokers in Switzerland. Eur Respir J. 2010;36:1259-1269.

51. Bárbara C, Rodrigues F, Dias H, et al. Chronic obstructive pulmonary disease prevalence in Lisbon, Portugal: the burden of obstructive lung disease study. Rev Port Pneumol. 2013;19:96-105.

52. Cardoso J, Ferreira JR, Almeida J, et al. Doença Pulmonar Obstrutiva Crónica em Portugal: estudo Pneumobil (1995) e estudo de prevalência de 2002 revisitados [Chronic obstructive pulmonary disease in Portugal: Pneumobil (1995) and 2002 prevalence studies revisited]. Rev Port Pneumol. 2013;19:88-95. Portuguese.

53. Mascarenhas J, Falcão H, Lourenço P, et al. Population-based study on the prevalence of spirometric obstructive pattern in Porto, Portugal. Respir Care. 2011;56:619-625.

54. Miravitlles M, Soriano JB, García-Río F, et al. Prevalence of COPD in Spain: impact of undiagnosed COPD on quality of life and daily life activities. Thorax. 2009;64:863-868.

55. Peña VS, Miravitlles M, Gabriel R, et al. Geographic variations in prevalence and underdiagnosis of COPD: results of the IBERPOC multicentre epidemiological study. Chest. 2000;118:981-989.

56. Cabrera López C, Juliá Serdá G, Cabrera Lacalzada C, et al. Prevalencia de la enfermedad pulmonar obstructiva crónica en las Islas Canarias [Prevalence of chronic obstructive pulmonary disease in the Canary Islands]. Arch Bronconeumol. 2014;50:272-277. Spanish.

57. Viegi G, Pedreschi M, Pistelli F, et al. Prevalence of airways obstruction in a general population: European Respiratory Society vs American Thoracic Society definition. Chest. 2000;117(5 Suppl 2):339S-345S.

58. Sichletidis L, Tsiotsios I, Gavriilidis A, et al. Prevalence of chronic obstructive pulmonary disease and rhinitis in northern Greece. Respiration. 2005;72:270-277.

59. Minas M, Hatzoglou C, Karetsi E, et al. COPD prevalence and the differences between newly and previously diagnosed COPD patients in a spirometry program. Prim Care Respir J. 2010;19:363-370.

60. Zachariades AG, Zachariadou T, Adamide T, Anagnostopoulou U, Georgiou A, Gourgoulianis KI. Prevalence of chronic obstructive pulmonary disease in Cyprus: a population-based study. COPD. 2012;9: 259-267.

61. Arslan Z, Ilgazlı A, Etiler N, Hamzaoğlu O. Prevalence of chronic obstructive pulmonary disease in Kocaeli: an industrialised city in Turkey. Balkan Med J. 2013;30:387-393. 
62. Erdogan A, Yimazel-Ucar E, Araz O, Saglam L, Mirici NA. Contribution of spirometry to early diagnosis of chronic obstructive pulmonary disease in primary health care centers. Turk J Med Sci. 2014;43: 690-694.

63. Gunen H, Hacievliyagil SS, Yetkin O, Gulbas G, Mutlu LC, Pehlivan E. Prevalence of COPD: first epidemiological study of a large region in Turkey. Eur J Intern Med. 2008;19:499-504.

64. Guerriero M, Caminati M, Viegi G, Senna G, Cesana G, Pomari C. COPD prevalence in a north-eastern Italian general population. Respir Med. 2015;109:1040-1047.

65. de Marco R, Accordini S, Cerveri I, et al. An international survey of chronic obstructive pulmonary disease in young adults according to GOLD stages. Thorax. 2004;59:120-125.

66. Chuchalin AG, Khaltaev N, Antonov NS, et al. Chronic respiratory diseases and risk factors in 12 regions of the Russian Federation. Int $J$ Chron Obstruct Pulmon Dis. 2014;9:963-974.

67. Artyukhov IP, Arshukova IL, Dobretsova EA, Dugina TA, Shulmin AV, Demko IV. Epidemiology of chronic obstructive pulmonary disease: a population-based study in Krasnoyarsk region, Russia. Int J Chron Obstruct Pulmon Dis. 2015;10:1781-1786.

68. Deveci F, Deveci SE, Türkoğlu S, et al. The prevalence of chronic obstructive pulmonary disease in Elazig, Eastern Turkey. Eur J Intern Med. 2011;22:172-176.

69. Amra B, Golshan M, Fietze I, Penzel T, Welte T. Correlation between chronic obstructive pulmonary disease and obstructive sleep apnea syndrome in a general population in Iran. J Res Med Sci. 2011;16: 885-889.

70. Golshan M, Amra B, Welte T. Sample survey of chronic obstructive pulmonary disease and associated risk factors in Isfahan, Iran. Tanaffos. 2011;10:32-36.
71. Al Zaabi A, Asad F, Abdou J, et al. Prevalence of COPD in Abu Dhabi, United Arab Emirates. Respir Med. 2011;105:566-570.

72. Al Ghobain M, Alhamad EH, Alorainy HS, Al Kassimi F, Lababidi H, Al-Hajjaj MS. The prevalence of chronic obstructive pulmonary disease in Riyadh, Saudi Arabia: a BOLD study. Int J Tuberc Lung Dis. 2015;19:1252-1257.

73. Waked M, Khayat G, Salameh P. Chronic obstructive pulmonary disease prevalence in Lebanon: a cross-sectional descriptive study. Clin Epidemiol. 2011;3:315-323.

74. Al Omari M, Khassawneh BY, Khader Y, Dauod AS, Bergus G. Prevalence of chronic obstructive pulmonary disease among adult male cigarettes smokers: a community-based study in Jordan. Int J Chron Obstruct Pulmon Dis. 2014;9:753-758.

75. Stav D, Raz M. Prevalence of chronic obstructive pulmonary disease among smokers aged 45 and up in Israel. Isr Med Assoc J. 2007;9; $800-802$.

76. El Rhazi K, Nejjari C, BenJelloun MC, El Biaze M, Attassi M, GarciaLarsen V. Prevalence of chronic obstructive pulmonary disease in Fez, Morocco: results from the BOLD study. Int J Tuberc Lung Dis. 2016 ; 20:136-141.

77. Adeloye D, Basquill C, Papana A, Chan KY, Rudan I, Campbell H. An estimate of the prevalence of COPD in Africa: a systematic analysis. COPD. 2015;12:71-81.

78. Cavalli-Sforza L, Menozzi P, Piazza A. The History and Geography of Human Genes. Princeton: Princeton University Press; 1996.

79. EuroVoc [webpage on the Internet]. Multilingual Thesaurus of the European Union. Available from: http://eurovoc.europa.eu/ drupal/?q=request\&uri=http://eurovoc.europa.eu/100277. Accessed November 24, 2017.
International Journal of COPD

\section{Publish your work in this journal}

The International Journal of COPD is an international, peer-reviewed journal of therapeutics and pharmacology focusing on concise rapid reporting of clinical studies and reviews in COPD. Special focus is given to the pathophysiological processes underlying the disease, intervention programs, patient focused education, and self management protocols.

\section{Dovepress}

This journal is indexed on PubMed Central, MedLine and CAS. The manuscript management system is completely online and includes a very quick and fair peer-review system, which is all easy to use. Visit http://www.dovepress.com/testimonials.php to read real quotes from published authors. 